\title{
The Fascio Effect: Biotin and Sleep
}

\author{
Kou Hayakawa ${ }^{1,2,3}$ \& Takeaki Nagamine ${ }^{4}$ \\ ${ }^{1}$ Graduate School of Health Sciences, Gunma University, Maebashi, Gunma, Japan \\ ${ }^{2}$ Graduate School of Agricultural and Life Sciences, The University of Tokyo, Bunkyo-ku, Tokyo, Japan \\ ${ }^{3}$ Department of Endocrinology and Metabolism, National Research Institute for Child Health and Development, \\ Setagaya-ku, Tokyo, Japan \\ ${ }^{4}$ Graduate School of Health Sciences, Gunma University, Maebashi, Gunma, Japan. \\ Correspondence: Kou Hayakawa, Graduate School of Health Sciences, Gunma University, Maebashi, Gunma, \\ Japan. Tel: 81-48-548-1733. E-mail: amokha123@true.ocn.ne.jp
}

Received: April 13, 2016 Accepted: April 26, 2016 Online Published: April 27, 2016

doi:10.5539/ijb.v8n3p22 URL: http://dx.doi.org/10.5539/ijb.v8n3p22

\begin{abstract}
An Italian maxim says "I bambini che dormono tanto crescono bene", and the English maxim also says that "All children need to sleep in order to grow and develop". In this review, we would like to demonstrate the truth of this proverb about sleep together with biotin (vitamin H) and lipoic acid (thioctic acid). Recently, we have found that D-biotin regulates the membrane biosynthesis in the cells. Previously, we have found that purified biotin-recycling enzyme biotinidase is also able to hydrolyze enkephalin and neuro-peptides. Thus, biotin state and sleep should be strongly linked to each other. In this report, we have investigated the expression of hormone receptors in some diseases using the new proteomics of protein-direct-microsequencing-deciphering (PDMD) method, and have indicated that having adequate sleep and nutrition is important to for healthy immunological and mental conditions in humans. It is also summarized that human breast milk is superior to bovine milk for human healthy babies to sleep and grow well.
\end{abstract}

Keywords: enkephalin, sleep, anorexia, biotin, lipoic acid, biotinidase, lipoamidase, Fascio effect

\section{Introduction}

A sleep-wake cycle is one of the factors that play into establishing a circadian rhythm, and this cycle contributes to some extent in establishing the timing of the circadian and other rhythms in humans. Growth factors of biotin (vitamin $\mathrm{H}$ ) and lipoic acid are both indispensable for living things, and they are biosynthesized by organisms with the exception of adult animals. When animals take these factors from other creatures, then these factors are designated as vitamins. Therefore, taking foodstuffs (nutrition) in animals is closely linked to neurons or nerve cells to support life and growth. Healthy adult humans cannot synthesize these vitamins, although fetal human tissues and cancer tissues can. Therefore, ingesting adequate amounts and recycling these vitamins by amidase enzymes of biotinidase (BIN) and lipoamidase (LIP) is an important factor for infant and adult humans (Hayakawa, 2015).

Human serum BIN (biocytinase) has been discovered in the human blood, and the enzyme activity has been shown to exhibit a day-to-day cyclic rhythm, although circadian rhythm has not yet been studied (Wright, Driscoll, \& Boger, 1954). BIN has also been discovered in the human breast milk (Oizumi \& Hayakawa, 1988), and human milk enzyme also has showed day-to-day and weekly cyclic rhythms, that may strongly be related to the menstrual cycle in two mothers ( $\mathrm{n}=2$, our unpublished observation). BIN is ubiquitously expressed in human and animal organs with the exception of saliva, lacrima, and umbilical cord (our unpublished observation), and this enzyme characteristics of cyclic rhythm may be present in the other organ-type BINs as human serum and milk.

Human serum BIN has been originally reported to show the molecular mass (Mr) 115,000 (Koivusalo \& Pispa, 1963). Thereafter, we have also reported the presence of biocytin-specific $110 \mathrm{kDa}$ BIN in the human serum (Oizumi \& Hayakawa, 1993). Human serum BIN as a monomer has been purified of Mr 68,000 sialylated-glycoprotein (Chauhan \& Dakshinamurti, 1986), and we also have found that 2.5 glycochains of $\mathrm{N}-/$ complex-/2- or 3-antenna types are attached to one molecule of serum BIN (Hayakawa, Yoshikawa, \& 
Watanabe, 1994). Therefore, human serum BIN has now been recognized as the dimer enzyme; i.e., 10-fold higher affinity for biocytin is obtainable in the dimer $(\mathrm{Km}=0.48 \mu \mathrm{M})$ than a monomer $(\mathrm{Km}=5.1 \mu \mathrm{M})($ Oizumi \& Hayakawa, 1993), and we would like to designate this 10-fold increasing phenomenon in the affinity by the association of monomer as Fascio effect (bundle or sheaf in Italian). Therefore, our results in Lewis rats suggest that the demonstrated organ differences in BIN $K \mathrm{~ms}$ are due to different subunit structures and glycochain structures, although the possibility of genetic differences among organs still remain (Hayakawa et al., 2006). Therefore, observed day-to-day cyclic rhythm of ca. 24hrs of serum- and milk- BIN might be due to this Fascio effect.

Further, we have firstly found and isolated the soluble-type BIN from porcine cerebrum, and $58 \%$ and $55 \%$ of the enzyme activity resides in the soluble subfractions in pig and human cerebrum, respectively (Oizumi \& Hayakawa, 1990a). On the other hand, over 95\% of LIP (lipoyl-X hydrolase) activity is present in the membrane subfractions of pig brain (Oizumi \& Hayakawa, 1990b), and it also possesses an acetylcholine esterase activity and an exopeptidase activity on physiological peptides (Oizumi \& Hayakawa, 1990c). Interestingly, human serum BIN possesses an amino-exopeptidase activity onto the opioid neuropeptides together with an amidase activity on the natural substrate of biocytin (biotinyl-lysine) (Oizumi \& Hayakawa, 1991). The Kms for Leu-enkephalin and Met-enkephalin by monomer serum-BIN show 303 and $385 \mu \mathrm{M}$, respectively (Oizumi \& Hayakawa, 1991), but dimer physiological-serum-BIN will show $39 \mu \mathrm{M}$ and possible tetramer BIN will show 4 $\mu \mathrm{M}$ accordingly by the Fascio effect. The Km of insulinase to insulin has been reportedly $62 \mu \mathrm{M}$ (Huet, Straßner, $\&$ Schaller, 2008). Then, human serum dimer-BIN will physiologically work on enkephalins and neuropeptides in the human blood. Since serum BIN is a multiple hydrolase and influences metabolism on many hormones, serum BIN has turned out to be one of the major components of serum proteins (ca. $0.3 \mathrm{mg} / \mathrm{mL}$ of serum) similar in concentration to ceruloplasmin and to serotransferrin (Abe et al., 2015). Therefore, it is discussed in this review that BIN and LIP in the brain is deeply linked to the neuropeptide metabolism influencing to the nutritional metabolism.

\section{Diseases}

\subsection{Meningitis}

Presence of BIN activity has been described in the human cerebrospinal fluid (CSF) (Suchy, McVoy, \& Wolf, 1985), however its physiological and or pathological role has not been discussed. We have reported the pathophysiological changes in the cerebrospinal-fluid BIN activity during bacterial meningitis caused by Staphylococcus aureus (De Felice et al., 1994). CSF-BIN may be produced and excreted into CSF by ependymocytes (glial cells) of choroid plexus (CP). CSF-BIN activity elevation correlates with elevation of body temperature (to $40.5^{\circ} \mathrm{C}$ ). This immediate elevation may be related to the increased level of enkephalin in CNS to prevent pain, then this exasperated state of enkephalin concentration should be lowered by activating the enkephalin hydrolysis by CSF-BIN (De Felice et al., 1994).

Enkephalin (opioid-neuropeptide) is known to co-exist simultaneously with neurotransmitters of nor-adrenaline (stress hormone or fight or flight response hormone) and serotonin (5-HT; vasoconstrictor hormone). Then, fever and pain are also associated with enkephalin. After about two weeks, the second elevation of BIN activity in CFS has again observed; i.e., the second peak of activity is coincided with the peak of bound-form $\mathrm{N}$-acetylneuraminic acid (NANA or sialic acid) content, which suggests the new synthesis of BIN. This second elevation of BIN after the 2 weeks may be linked to get acquired immunity; i.e., this new BIN synthesized 2-weeks later seems to be the fetal/inflammatory-BIN as reported (Abe et al., 2015). Then, this secondary synthesis of fetal/inflammatory-BIN may occur in the leukocytes of CSF to increase the immunity against Staphylococcus aureus.

\subsection{Gait Disorder with Biotin Deficiency in the Adults}

Gait disorder associated with biotin deficiency and contraction is a disease of the cerebellum or central nervous system (CNS). A patient of severe gait disorder and contraction (32 y, adult female) has shown thermo-instable serum BIN; i.e., her $\mathrm{Km}$ value becomes 8.6-fold larger from 4.45 to $38.2 \mu \mathrm{M}$ after heat pretreatment $\left(37{ }^{\circ} \mathrm{C}\right.$ for $4 \mathrm{~h}$ ) (Abe et al., 2015). Her serum total biotin is low, $1.14 \mu \mathrm{g} / \mathrm{mL}$ serum, as compared to healthy subjects $(\mathrm{n}=4$; median $1.95 \mu \mathrm{g} / \mathrm{mL}$ of serum, range $1.80-2.05 \mu \mathrm{g} / \mathrm{mL}$ of serum), and thermo-lability of BIN is understood to be strongly related to the state of biotin deficiency. Thus, her younger sister $(22 \mathrm{y}$, adult female; with light gait disorder and contraction) has shown similar thermo-instability; i.e., $K \mathrm{~m}$ value becomes 2.5 -fold larger from 6.83 to $17.2 \mu \mathrm{M}$ by the same heat pretreatment, and her biotin is relatively low $1.29 \mu \mathrm{g} / \mathrm{mL}$ serum. Therefore, this younger sister is also considered to have light biotin deficiency. The heat-instability in $\mathrm{Km}$ of serum BIN of 
biotin-deficient patients' may be due to the easier dissociation from dimer into monomer, and this easier dissociation may be caused by the changed glycochain structure of the serum BIN.

Biotin is a regulator of membrane biosynthesis as indicated (Abe et al., 2015), and leaks of the membrane-receptor and membrane-transport proteins are increased due to the gait disorder as shown in Table 1 (healthy median value; $30.7 \mu \mathrm{g} / \mathrm{mg}$ of serum protein, versus patients' median value; $67.1 \mu \mathrm{g} / \mathrm{mg}$ of serum protein). Thus, these two patients' membrane proteins in the CNS may have been reduced, although soluble-hormone metabolism may not be changed. These two patients' sera also contain ceruloplasmin fragment (214-; -KHI / DRE-), which is a serum marker of inflammation/infection as reported (Abe et al., 2015), and also indicated in Table 1 as a reference.

Table 1. Amount of membrane receptors together with membrane transporters found in the adult human serum (non cancer)

\begin{tabular}{|c|c|c|}
\hline Healthy adult (33y, male) & & \\
\hline Activin receptor type IIA (244-) & & 10.3 \\
\hline Macrophage mannose receptor 1 (466-) & & 9.7 \\
\hline $\begin{array}{l}\text { Scavenger receptor cysteine-rich type } 1 \text { protein (Hemoglobin scavenger receptor; } \\
286-\text { ) }\end{array}$ & & 9.1 \\
\hline Sodium-dependent neutral amino acid transporter B(0) (581-) & & 10.1 \\
\hline Inflammation marker; Ceruloplasmin (214-1065 of precursor) & Total & $\begin{array}{r}39.2 \mu \mathrm{g} / \mathrm{mg} \text { of serum protein } \\
0.0 \mu \mathrm{g} / \mathrm{mg} \text { of serum protein }\end{array}$ \\
\hline \multicolumn{3}{|l|}{ Healthy adult ( $52 \mathrm{y}$, female; the mother of the gait disorder patient) } \\
\hline Ryanodine receptor 1 (3993-) & & 6.7 \\
\hline Interleukin-31 receptor $\mathrm{A}(1-)$ & & 4.7 \\
\hline Olfactory receptor $52 \mathrm{~W} 1(177-320)$ & & 4.6 \\
\hline Olfactory receptor 5B2 (168-309) & & 3.4 \\
\hline Uromodulin-like 1 (Olfactorin; 896-) & & 2.7 \\
\hline Ceruloplasmin (214-1065 of precursor) & Total & $\begin{array}{r}22.1 \mu \mathrm{g} / \mathrm{mg} \text { of serum protein } \\
0.0 \mu \mathrm{g} / \mathrm{mg} \text { of serum protein }\end{array}$ \\
\hline \multicolumn{3}{|c|}{ The younger sister of severe gait disorder patient ( $22 \mathrm{y}$, female; light gait disorder patient with light contraction) } \\
\hline Plexin-A1 (Semaphorin receptor NOV ; 835-1896) & & 9.4 \\
\hline Olfactory receptor $11 \mathrm{H6}(155-330)$ & & 7.8 \\
\hline G-protein coupled receptor PGR24 (Adhesion G-protein coupled receptor D2; & & 6.7 \\
\hline Sodium/calcium exchanger 3 (735-) & & 6.9 \\
\hline Dual oxidase 2 (NADH/NADPH thyroid oxidase p138-tox ; 1259-1548) & & 15.6 \\
\hline Synaptogyrin-4 (168-) & & 14.7 \\
\hline Inward rectifier $\mathrm{K}(+)$ channel Kir $2.4(78-)$ & & 3.1 \\
\hline Ceruloplasmin (214-1065 of precursor) & Total & $\begin{array}{l}64.2 \mu \mathrm{g} / \mathrm{mg} \text { of serum protein } \\
5.8 \mu \mathrm{g} / \mathrm{mg} \text { of serum protein }\end{array}$ \\
\hline
\end{tabular}

Severe gait disorder patient with contraction (narrowing of visual field; biotin deficiency; Severe gait disorder and contraction)

\begin{tabular}{lr} 
Plexin-A3 (Semaphorin receptor SEX; 1807-1871) & 9.9 \\
Olfactory receptor 8U9 (95-309) & 6.6 \\
Olfactory receptor 4K3 (110-315) & 5.1 \\
Epidermal growth factor receptor 5 (EGFR-5; 129-) & 2.3 \\
Lectomedin-3 (Latrophilin-3; Adhesion G protein-coupled receptor L3; 1227-) & 5.6 \\
Probable phospholipid-transporting ATPase IB (1049-) & 12.2 \\
Potassium channel subfamily K member 1 (290-) & 11.4 \\
Chloride channel protein 4 (585-) & 8.9 \\
Sodium channel protein type 8 subunit alpha (710-) & 8.0 \\
& Total \\
Inflammation marker; Ceruloplasmin (214-1065 of precursor) & $4.2 \mu \mathrm{g} / \mathrm{mg}$ of serum protein \\
\hline
\end{tabular}

PDMD method was used (Abe et al., 2015). As a reference, the serum marker of inflammation of ceruloplasmin fragment (214- ; $-I / D-)$ amount is also indicated. 
Therefore, we have searched for the peptidase which can specifically cleave the sequence of -KHI / DRE-, and have found the putative enzyme to produce the ceruloplasmin fragment in two sisters' serum. Chymotrypsin-like serine proteases may be able to produce the ceruloplasmin fragment (214-); i.e., genome polyprotein of Yellow fever virus (480-3411; containing serine protease NS3) is found at $6.1 \mu \mathrm{g} / \mathrm{mg}$ of serum protein in elder sister, and serine protease of polyserase-2 is also found at $12.3 \mu \mathrm{g} / \mathrm{mg}$ of serum protein in younger sister, respectively. On the other hand, two healthy adults have no serine protease, though healthy adult (33y, male) has cysteine protease of calpain-11 in his serum.

Further, LIP may possess such a peptidase activity; i.e., LIP from pig brain can hydrolyze Asp-Phe-OMe (aspartame), but cannot hydrolyze Asp-Phe (Oizumi \& Hayakawa, 1990c). Although the sister's serum contained no LIP, this severe patient's serum possesses the lipase member H (101-), and may be working as LIP (Hui, Hayakawa, \& Oizumi, 1993).

\subsection{Biotin Deficiency with Alopecia in Children}

Biotin deficiency in the child induces dermatitis and alopecia (Abe et al., 2015). Appearance of keratin-associated protein (KAP) and olfactory receptor (OR) in the patients' serum occurs, and these hydrophobic proteins disappear after biotin administration (Abe et al., 2015).

The appearance of membrane receptor proteins in these sera has been re-investigated using our data set, and summarized in Table 2. Membrane-receptor proteins do not appear in the two non-biotin-deficient girls' sera (Table 2) in contrast to two healthy adults' sera (Table 1). This indicates that the membrane-receptor in the non-biotin-deficient infants' neuronal cells is strictly produced and leaking from the membranes to blood is not occurred during infancy. On the other hand, the production of nerve-cell membranes in healthy adults is performed more loose manner which indicates that the ageing in the human brain or CNS arises from young ages of human life. Similar unique observation that the connectin/titin only appears in the adult's serum has already been reported recently by us (Abe et al., 2015).

On the other hand, membrane-receptor proteins appear in the biotin-deficient patient $1(1 \mathrm{y}$, female $)$ at 12.2 $\mu \mathrm{g} / \mathrm{mL}$ of serum protein before the biotin therapy, and then decreases to $4.1 \mu \mathrm{g} / \mathrm{mL}$ of serum protein at 16 weeks of therapy (Table 2). However, membrane-receptor proteins again increased to $43.4 \mu \mathrm{g} / \mathrm{mL}$ of serum protein at 44 weeks of therapy, which suggests that the excess symptom of biotin has occurred. Therefore, biotin is expected to be the regulator for membrane biosynthesis (Abe et al., 2015); i.e., excess biotin has induced the excretion of membrane-protein receptors into the blood.

Inflammation was worse at 44 weeks in this patient with complications of anorexia, and the appearance of possible immunoglobulin $\mathrm{M}$ occurring as described below, although the level of inflammatory- ceruloplasmin fragments are not as affected; i.e., inflammatory-ceruloplasmin is $3.0,4.4$, and $3.1 \mu \mathrm{g} / \mathrm{mL}$ of serum protein at 0 , $16 \mathrm{w}$, and $44 \mathrm{w}$, respectively. Such proteases possible to produce the ceruloplasmin-fragment are constantly present in her sera; i.e., probable serine protease HTRA4 in time-zero's serum (before biotin therapy), aminopeptidase E of Lactobacillus helveticus in 16 weeks' serum, and pol polyprotein of Murine leukemia virus and replicase polyprotein 1a of Human coronavirus OC43 in 44 weeks' serum are observed, respectively. Therefore, she has been in a constant state of inflammation, although the alopecia is healed.

Similarly, appearance of KAP and OR in the other two infant-patients' serum has been observed (Abe et al., 2015). A biotin-deficient patient 2 (3 mo, male) before biotin therapy shows $17.4 \mu \mathrm{g} / \mathrm{mL}$ of membrane-protein receptors, but this patient's serum after the 13 weeks of biotin therapy decreased to $12.4 \mu \mathrm{g} / \mathrm{mL}$ (Table 2). This patient's inflammation seems to be healed by biotin therapy; i.e., replicase polyprotein 1a of Feline infectious peritonitis virus found before the therapy, and this may have produced the inflammatory ceruloplasmin-fragment, but is absent from the serum after 13 weeks of therapy. Although the serum of 13-weeks therapy contains the enzyme of gag polyprotein from Koala retrovirus, which can produce the fragment, the increased alpha 2-macroglobulin in serum (from 1.5 to $9.5 \mu \mathrm{g} / \mathrm{mL}$ of serum protein) may have prevented the ceruloplasmin-fragment production in the 13-week's serum. Non-biotin-deficient children have no such cat's and/or marsupial koala's virus, and it is not known at this time that how this patient 2 has acquired these vira.

Another biotin-deficient patient 3 ( 3 y, female; with GSD1b) also has shown relatively high membrane-protein receptors in her serum before biotin therapy $(21.3 \mu \mathrm{g} / \mathrm{mL}$ of serum protein), which also suggests the scanty of biotin may induce the excretion of membrane proteins into the blood. However, this patient after biotin therapy for 8 months shows an extremely increased membrane-protein receptors $(101.5 \mu \mathrm{g} / \mathrm{mL}$ of serum protein), which may be due to the aftereffect of the liver transplantation (after 2 months). Concentration of inflammatory ceruloplasmin-fragment is not changed; i.e., 3.4 and $4.1 \mu \mathrm{g} / \mathrm{mL}$ of serum protein before and after the biotin therapy, respectively. This suggests that the first inflammation is due to biotin-deficiency (before therapy; 
replicase polyprotein 1a of Murine hepatitis virus is found, and may have produced the fragment) and second one is due to the liver transplantation (in this case, human protease of cathepsin $\mathrm{S}$ is found and may have produced the fragment).

Table 2. Amount of membrane receptors in the biotin-deficient with alopecia children's serum

\begin{tabular}{|c|c|c|}
\hline \multirow{2}{*}{$\begin{array}{l}\text { Children } \\
\text { Non-biotin-deficient child a }\end{array}$} & \multicolumn{2}{|c|}{ Amount of membrane receptors } \\
\hline & Total & $0.0 \mu \mathrm{g} / \mathrm{mg}$ of serum protein \\
\hline Non-biotin-deficient child b & Total & $0.0 \mu \mathrm{g} / \mathrm{mg}$ of serum protein $\mu$ \\
\hline \multicolumn{3}{|l|}{ Biotin-deficient patient 1 (before biotin treatment) } \\
\hline Olfactory receptor $4 D 1$ (95-310) & 7.3 & \\
\hline \multirow[t]{2}{*}{ Regulator of G-protein signaling 19 (36-) } & 4.9 & \\
\hline & Total & $12.2 \mu \mathrm{g} / \mathrm{mg}$ of serum protein \\
\hline \multicolumn{3}{|l|}{ Biotin-deficient patient 1 (after biotin treatment; 16 weeks and healthy) } \\
\hline \multirow[t]{2}{*}{ Activin receptor type-2B (153-) } & 4.1 & \\
\hline & Total & $4.1 \mu \mathrm{g} / \mathrm{mg}$ of serum protein \\
\hline \multicolumn{3}{|c|}{ Biotin-deficient patient 1 (after biotin treatment; 44 weeks; healthy but inflammatory with anorexia) } \\
\hline \multicolumn{3}{|l|}{ Macrophage mannose receptor $1(1387-) \quad 23.1$} \\
\hline Somatostatin receptor-interacting protein (Synamon; 995-) & 6.1 & \\
\hline Somatostatin receptor-interacting protein (Synamon; 1005-) & 5.9 & \\
\hline$\beta-3$ Adrenergic receptor (75-) & 3.6 & \\
\hline Atrial natriuretic peptide receptor A (571-) & 3.0 & \\
\hline \multirow[t]{2}{*}{ Epidermal growth factor (Urogastrone; 1036-1207) } & 1.8 & \\
\hline & Total & $43.4 \mu \mathrm{g} / \mathrm{mg}$ of serum protein \\
\hline \multicolumn{3}{|l|}{ Biotin-deficient patient 2 (before biotin treatment) } \\
\hline Transmembrane 6 superfamily member $2(81-)$ & 7.8 & \\
\hline GABA-B receptor-binding protein (433-) & 4.5 & \\
\hline Olfactory receptor $2 A G 2(77-316)$ & 2.8 & \\
\hline \multirow[t]{2}{*}{ Tumor necrosis factor receptor superfamily member $1 \mathrm{~A}(53-)$} & 2.3 & \\
\hline & Total & $17.4 \mu \mathrm{g} / \mathrm{mg}$ of serum protein \\
\hline \multicolumn{3}{|l|}{ Biotin-deficient patient 2 ( 13 weeks after biotin treatment; healthy) } \\
\hline Integrin $\beta-1$ (Fibronectin receptor subunit beta; $458-$ ) & 8.9 & \\
\hline \multirow[t]{2}{*}{ Neuronal acetylcholine receptor subunit alpha-10 (3-) } & 3.6 & \\
\hline & Total & $12.4 \mu \mathrm{g} / \mathrm{mg}$ of serum protein \\
\hline \multicolumn{3}{|l|}{ Biotin-deficient patient 3 (before biotin treatment and before the liver transplantation) } \\
\hline Olfactory receptor 5 A2 (21-324) & 8.6 & \\
\hline Interleukin-9 receptor (295-) & 6.4 & \\
\hline \multirow[t]{2}{*}{ Serotonin receptor 4 (169-) } & 6.3 & \\
\hline & Total & $21.3 \mu \mathrm{g} / \mathrm{mg}$ of serum protein \\
\hline \multicolumn{3}{|l|}{ Biotin-deficient patient 3 (2 mo after the transplantation; 8 mo after biotin treatment) } \\
\hline Membrane-spanning 4-domains subfamily A member 10 (CD20 antigen-like 7; 136-) & 63.5 & \\
\hline Integrin $\alpha-4 \quad(55-)$ & 16.9 & \\
\hline Mannose receptor-like protein 2 (285-) & 13.2 & \\
\hline Receptor tyrosine-protein kinase ErbB-1 (EGF receptor; 280-) & 5.4 & \\
\hline Tyrosine-protein kinase receptor ETK1 (562-) & 2.4 & \\
\hline & Total & $101.5 \mu \mathrm{g} / \mathrm{mg}$ of serum protein \\
\hline
\end{tabular}

${ }^{*}$ PDMD method was used (Abe et al., 2015).

Non-biotin-deficient child a is $8 \mathrm{mo}$ girl with gastritis, and non-biotin-deficient child $\mathrm{b}$ is the same girl at $12 \mathrm{mo}$ with common cold and inflammation.

Biotin-deficient patient 1 is a $1 \mathrm{y}$ girl.

Biotin-deficient patient 2 is a 3 mo boy.

Biotin-deficient patient 3 is a 3 y girl with GSD1b. 
Therefore, it is also shown that biotin deficiency in the child induces the leaking of membrane-protein receptors of mainly brain origin into the blood (Table 2), as reported similarly with respect to KAP and OR (Abe et al., 2015).

Furthermore, biotin is a regulator of membrane biosynthesis as already indicated (Abe et al., 2015), and the leaks of membrane kidney-BIN and L-alanine from the kidney into the urine have been also observed in patients (age; median 13 years, range 3-26 years) with insulin-dependent diabetes mellitus (IDDM) (Terentyeva, Hayakawa, et al., 1997, pp. 21-24). Since biotin deficiency is occurring among IDDM patients, injured membrane structure would have occurred; i.e., injured metabolism in membrane biosynthesis will induce diabetic nephropathy (among $35 \%$ of IDDM patients) and diabetic neuropathy (among $20 \%$ of IDDM patients). The adequate membrane biosynthesis is essential to maintain the morphology of the cell (Matsuzawa, Hayakawa, et al., 1973, pp. 436-442). Therefore, having adequate biotin, L-alanine, and sleep in these IDDM patient is recommended to prevent the threatening prognosis of diabetic nephropathy and neuropathy.

\subsection{Anorexia with Weight Loss}

Anorexia is a severe disease related to hormone metabolism. Representative appetite-controlling hormones are ghrelin (an $O$-octanoylated or $O$-decanoylated 27-mer and 28-mer peptide) (Kojima et al., 1999), orexin (33-mer and 28-mer peptide) (Sakurai et al., 1998), leptin (possibly $O$-glycosylated protein of $M \mathrm{r} 16,026)$ (Halaas et al., 1995; Klok, Jakobsdottir, \& Drent, 2007), and insulin (protein of Mr 5807) (Banting et al., 1922). We have previously found the patient of excess biotin disease, who took $10 \mathrm{mg}$ /day biotin for 44 weeks (or for 11 months) and demonstrated anorexia with weight loss (Abe et al., 2015; Biotin-deficient patient 1 in Table 2). The serum of the anorexia patient has showed the presence of the membrane-receptor proteins such as macrophage mannose receptor, somatostatin receptor-interacting protein (synamon), $\beta-3$ adrenergic receptor, atrial natriuretic peptide receptor A, and epidermal growth factor (urogastrone) $(43.4 \mu \mathrm{g} / \mathrm{mg}$ of serum protein; Table 2). Therefore, these excreted membrane proteins in the serum may have induced her anorexia; i.e., these membrane proteins found in her serum should be present in the cellular membrane compartment. Since scanty of biotin causes depression and anorexia (Levenson, 1983), direct effect of excess biotin to her membrane biosynthesis in CNS is still remained (Hayakawa, 2015).

This patient also demonstrated exasperated immunity or inflammation; i.e., her serum at $44 \mathrm{w}$ of biotin treatment contains Ig $\lambda$ chain $V$ region $4 \mathrm{~A}$ (without cutting putative signal-peptide region) $30.2 \mu \mathrm{g} / \mathrm{mg}$ serum protein, and $\operatorname{Ig} \mu$ chain $\mathrm{C}$ region $2.5 \mu \mathrm{g} / \mathrm{mg}$ serum glycoprotein (heavy chain of inflammatory $\operatorname{IgM}$ ), but her sera at 0 and 16 $\mathrm{w}$ of therapy do not. Interestingly, we investigated 10 sera (from children and adults) showing no Ig proteins (data not shown).

Anorexia nervosa in this patient might be caused by the autoimmunity against ghrelin (Terashi et al., 2011). On the other hand, brain LIP is able to hydrolyze the physiologically active-form of ghrelin (an anchored form at $3^{\text {rd }}$ serine by O-octanoyl or O-decanoyl residue is physiologically active); i.e., brain-LIP has higher specificity to hydrophobic molecules (Oizumi \& Hayakawa, 1990c), and also has a de-anchoring activity to NADH cytochrome $b_{5}$ reductase ( $N$-myristoyl residue at $2^{\text {nd }}$ glycine) (Oizumi \& Hayakawa, 1992). Thus, brain-LIP seems to release the $O$-octanoyl or $O$-decanoyl residue at $3^{\text {rd }}$ serine of ghrelin. Further, brain-LIP may also release the possible $O$-octanoyl or $O$-decanoyl residue at $2^{\text {nd }}$ serine of orexin. Therefore, brain-LIP can extinguish the appetite-stimulating signals, and may have induced her anorexia.

Both monomer-form of BIN and LIP apparently appears unable to extinguish the appetite-suppressing signal of insulin, since this protein (without anchor) are too large to be handled by monomer BIN (Oizumi \& Hayakawa, 1991). On the other hand, tetramer molecule of avidin (Mr 64,000; monomer Mr 16,000) is a strong binding protein to biotin/lipoic acid due to the Fascio effect, and can bind to biotin residue of bacterial pyruvate carboxylase (Mr 508,000) to inhibit the enzyme activity (Chern, Kusaka, \& Fukui, 1976). The partially purified pyruvate carboxylase is pretreated with avidin at $0{ }^{\circ} \mathrm{C}$ for $15 \mathrm{~min}$, and then is tested; i.e., $75 \%$ inhibition is achieved (Chern, Kusaka, \& Fukui, 1976). Thus, tetramer avidin shows such a strong binding affinity to only the $0.05 \%$ of biotin portion in the protein substrate of pyruvate carboxylase. Previously, purified monomer-form BIN and LIP have not been able to liberate biotin (Chauhan \& Dakshinamurti, 1986) and lipoic acid (Oizumi \& Hayakawa, 1989) from large $M r$ protein-substrate of pyruvate carboxylase $(M \mathrm{r} 518,536)$ and pyruvate dehydrogenase (Mr 3,164,004), respectively. Then, dimer or tetramer BIN and/or LIP may be working in the organs to liberate biotin or lipoic acid from the large proteins due to the Fascio effect. Although monomer BIN and/or LIP can hydrolyze short neuro-peptide, the multimer of BIN and/or LIP may be able to hydrolyze the large $\mathrm{Mr}$ protein substrate of insulin to extinguish the appetite-suppressing signal, although leptin is too large to be hydrolyzed. Therefore, the multimer of BIN and/or LIP may become the physiological therapeutic-drug for anorexia. 
This anorexia patient demonstrated an excess-biotin condition at 44 weeks' of biotin therapy (Abe et al., 2015), but high biotin level would not inhibit the de-anchoring activity of brain-LIP, which has no affinity to biotin and biotinyl-amide-compounds (Oizumi \& Hayakawa, 1990b). De-anchoring activity of brain-LIP is strongly inhibited by lipoyl-lysine and lipoic acid (Oizumi \& Hayakawa, 1992). Therefore, therapy by lipoyl-lysine and lipoic acid might be a possible choice to treat her anorexia.

Ghrelin (appetite-regulating hormone) is a stomach hormone signaling onto the pituitary, where the growth hormone secretagogue receptor type 1 (GHSR) is stimulated and growth hormone excretion occurs. GHSR also binds to the other growth hormone releasing peptides (GHRP) such as Met-enkephalin. Therefore, Met-enkephalin is also able to work similarly as ghrelin via GHSR. Human serum BIN is a unique exo-aminopeptidase (Oizumi \& Hayakawa, 1991) of the opioid neuropeptide Met-enkephalin (Hughes et al., 1975 ) and $\delta$ sleep-inducing peptide (DSIP) (Monnier, Dudler, et al., 1977). Sleep also induces growth hormone excretion (Van Cauter et al., 1996) and ghrelin excretion (Weikel et al., 2003), and possibly many other neuronal hormones. Sleep is deeply linked to the circadian rhythm, and BIN shows cyclic pattern in the activity. The secretions of many neuronal hormones are linked strongly to the sleep; i.e., that is why children only grow during sleep. Therefore, the therapy by sleep might also have been possible to cure her anorexia, although the precise mechanism of BIN on sleep has not yet been clarified.

\subsection{Tissue Membrane-Protein Receptors Synthesis and Liver Diseases}

Cultured cells synthesize membrane-protein receptors as shown in Table 3.

Table 3. Amount of membrane receptors in cultured cells

\begin{tabular}{|c|c|c|}
\hline \multicolumn{3}{|l|}{ Normal fetal liver cells (Hc cells) } \\
\hline Melanocortin receptor 5 (147-) & sup & 4.1 \\
\hline Olfactory receptor 56A3 (138-) & sup & 8.1 \\
\hline \multicolumn{3}{|c|}{$\begin{array}{r}\text { Total } 12.2 \mu \mathrm{g} / \mathrm{mg} \text { of cellular proteins } \\
\text { (all comes in supernatant fraction) }\end{array}$} \\
\hline \multicolumn{3}{|l|}{ HepG2, +fucoidan (cured) } \\
\hline Acetylcholine receptor protein subunit $\delta$ & membrane & 0.83 \\
\hline$\beta-1$ Adrenergic receptor (431-) & membrane & 0.58 \\
\hline \multirow[t]{2}{*}{ Relaxin receptor 2 (731-754) } & membrane & 6.0 \\
\hline & $\begin{array}{l}.44 \mu \mathrm{g} / \mathrm{mg} \text { of cell } \\
1 \text { comes in membr }\end{array}$ & $\begin{array}{l}\text { teins } \\
\text { ction) }\end{array}$ \\
\hline \multicolumn{3}{|l|}{ HepG2, - fucoidan (state of cancer) } \\
\hline Insulin receptor substrate 2 (IRS-2; 1187-) & membrane & 0.47 \\
\hline Insulin receptor substrate 2 (IRS-2; 368-) & membrane & 12.2 \\
\hline Dopamine D4 receptor (107-) & sup & 2.5 \\
\hline GABA(A) receptor subunit $\pi \quad$ (Internal 14mer; 418-431) & membrane & 0.13 \\
\hline GABA(A) subunit $\gamma-2$ & membrane & 1.3 \\
\hline Leptin receptor overlapping transcript-like 1 (105-) & membrane & 0.08 \\
\hline Macrophage mannose receptor 2 (597-1479) & sup & 6.1 \\
\hline Odorant receptor HOR5' $\beta 2 \quad$ (27-) & membrane & 0.86 \\
\hline Olfactory receptor 4M1 (61-) & membrane & 0.80 \\
\hline Olfactory receptor 52B6 (150-) & membrane & 0.52 \\
\hline Opsin-3 (14-) & membrane & 1.2 \\
\hline Ryanodine receptor 1 (RyR1; Skeleta; muscle-type; 4427-) & sup & 4.2 \\
\hline Taste receptor type 2 member 42 (236-314) & membrane & 0.24 \\
\hline TGF-III receptor type III (84-) & membrane & 2.4 \\
\hline Vanilloid receptor-like protein 2 (107-) & sup & 5.3 \\
\hline X-linked interleukin-1 receptor accessory protein-like 1 (547-) & sup & 1.0 \\
\hline
\end{tabular}

Total $39.4 \mu \mathrm{g} / \mathrm{mg}$ of cellular proteins (51.3\% comes into the membrane fraction)

${ }^{*}$ PDMD method was used (Abe et al., 2015). Membrane was defined as a subfraction that precipitated with an ultracentrifuge machine at $100,000 \mathrm{xg}, 90 \mathrm{~min}$, at $4{ }^{\circ} \mathrm{C}$. 
Interestingly, fetal liver cells (Hc cells) synthesize very small amounts of membrane-protein receptors, which is similar to the result of infant's serum without biotin deficiency (see Table 2); i.e., few membrane-protein receptors are synthesized and no excretion into the blood occurs. Further, synthesized membrane-protein receptors in fetal $\mathrm{Hc}$ cells seem not to be integrated into the membrane structure; i.e., all the receptors are found in the cytoplasmic soluble sub-fraction (Table 3). On the other hand, adult cancer cells of HepG2 (age 15 years old) synthesize large amounts of membrane-protein receptors (without fucoidan; Table 3), which suggests that liver cancer is a disease deeply related to the differentiation; i.e., cancer cells in hepatocellular carcinoma (HCC) becomes similar to the neuronal cells. Further, half of membrane receptors synthesized is integrated into the membrane structure (without fucoidan), but all the synthesized membrane receptors in cured-state HepG2 cells (with fucoidan) integrates into the membrane structure (Hayakawa \& Nagamine, 2014) (Table 3). Synthesized membrane receptors in the cancer HepG2 cells may have been fragmented or glycosylated post-translationally, and half of them appear in the cytoplasmic supernatant sub-fraction.

With respect to differentiation, we previously have found that histone H3.1 is highly expressed and becomes the major protein in the immortal cultured-cells (Hayakawa et al., 2003). These immortal cells highly biosynthesize biotin (Keränen, 1972), and biotinylation onto the lysine residues of histone H3.1 may occur (Kothapalli et al., 2005). Although, cancer-tissue cells do not actively synthesize the histone H3.1, high content of biotin in cancer tissues (Hayakawa \& Nagamine, 2009) may biotinylate histone H3.1, this may cause the enhancement of the synthesis of the membrane-protein receptors to occur.

Furthermore, we have previously found that the sexual differentiation induced by a peptide hormone induces changes in gene expression for only three soluble proteins (Hayakawa \& Fukui, 1980). Therefore, we have expected that the differentiation caused by cancer also might induce changes in some group of membrane-protein receptors. As shown in Table 3, the group of membrane-protein receptors in HepG2 has been decreased by the fucoidan treatment. Exasperated biosynthesis of the group of membrane-protein receptors is also observable in the tissues of liver diseases including pseudo-cancer (Tables 4-1 and 4-2). The residence at the membrane fraction is decreased to $6.2 \%$ in the HCC portion (No. 6 patient) from $68.6 \%$ in the LC portion (No. 6 patient). Therefore, the repression of synthesis of the group of membrane-protein receptors by fucoidan is expected to occur including pseudo-cancer liver. Thus, fucoidan would be the best of all medicines.

Table 4-1. Amount of membrane receptors in the tissue-liver cells (biopsy)

\begin{tabular}{lll}
\hline Pseudo Liver Cancer (not in the state of cancer) & & \\
C5A Anaphylatoxin chemotactic receptor (C5A-R; 269-) & membrane & 0.31 \\
Cannabinoid receptor 1 (CB1; CB-R; 198-) & membrane & 1.1 \\
CD44 antigen (Hyaluronate receptor; 481-) & membrane & 1.5 \\
ER lumen protein retaining receptor 3 (KDEL receptor 3; 50-) & membrane & 0.82 \\
fMLP-related receptor II (FMLP-R-II; 262-) & sup & 2.7 \\
Granulocyte-macrophage colony-stimulating factor receptor $\alpha$ chain (GM-CSF-R; 13-) & membrane & 2.9 \\
Mas-related G-protein coupled receptor member X3 (68-) & membrane & 1.6 \\
Melanocyte stimulating hormone receptor (MSH-R; 80-) & sup & 3.6 \\
Neuropeptide Y receptor type-1 (NPY1-R; 92-) & sup & 8.8 \\
Olfactory receptor 5B13 or 1M1 (66-) & membrane & 1.0 \\
Oxytocin receptor (OT-R; 127-) & sup & 6.0 \\
Ryanodine receptor, skeletal muscle (3991-5038) & membrane & 8.5 \\
Ryanodine receptor, skeletal muscle (4701-5038) & membrane & 2.7 \\
Serine/threonine-protein kinase receptor R5 (ALK-3; 380-) & membrane & 1.7 \\
Somatostatin receptor Type 3 (SS3R; 404-) & membrane & 0.11 \\
Tyrosine-protein kinase receptor TIE (92-) & membrane & 8.2 \\
Vasopressin V1A receptor (Antiuretic hormone receptor 1a; 239-) & membrane & 1.7 \\
\hline
\end{tabular}


Total $53.2 \mu \mathrm{g} / \mathrm{mg}$ of cellular proteins

( $60.4 \%$ comes into the membrane fraction)

\section{Liver Cirrhosis (with Leprosy; not in the state of cancer)}

Acetylcholine receptor protein, $\delta$ chain (257-)

$\begin{array}{ll}\text { sup } & 2.9 \\ \text { sup } & 22.0 \\ \text { sup } & 2.8 \\ \text { membrane } & 0.88 \\ \text { membrane } & 2.8 \\ \text { sup } & 8.4 \\ \text { sup } & 4.5 \\ \text { membrane } & 2.8 \\ \text { membrane } & 4.4 \\ \text { sup } & 2.3 \\ \text { sup } & 1.5 \\ \text { membrane } & 2.8\end{array}$

CI Man-6-P receptor (Insulin-like growth factor II receptor; 509-)

Calcitonin receptor (CT-R; 267-)

Mas-related G protein-coupled receptor MRG (301-)

Neuromedin K receptor (NKR; NK-3R; 146-)

Neuronal acetylcholine receptor protein, $\alpha-5$ chain (93-)

Neuronal acetylcholine receptor protein, $\beta-4$ chain (60-)

Putative tachykinin receptor (122-)

Serine/threonine-protein kinase receptor R4 (ALK-5; 16-)

Total $57.9 \mu \mathrm{g} / \mathrm{mg}$ of cellular proteins
$6 \%$ comes into the membrane fraction)

Serotonin receptor (5-HT-1F; 186-)

Somatostatin receptor type 2 (245-)

Substance-P receptor (SPR; NK-1R; 93-)

Liver Cirrhosis portion (No. 6 patient; not in the state of cancer)

Alpha-2C-1 Adrenergic receptor, subtype C4 (415-)

$\begin{array}{ll}\text { sup } & 1.1 \\ \text { membrane } & 3.3 \\ \text { membrane } & 5.2 \\ \text { membrane } & 0.79 \\ \text { membrane } & 1.9 \\ \text { membrane } & 1.9 \\ \text { membrane } & 1.2 \\ \text { membrane } & 1.8 \\ \text { sup } & 8.5 \\ \text { sup } & 2.2 \\ \text { membrane } & 9.4 \\ \text { membrane } & 0.37\end{array}$

Growth hormone-releasing hormone receptor (GRFR; 76-)

Mas-related G protein-coupled receptor MRG (3-)

Melanocortin-5 receptor (MC5-R; 171-)

Muscarinic acetylcholine receptor M4 (385-)

Muscarinic acetylcholine receptor M4 (393-)

Neuronal acetylcholine receptor protein $\alpha-5$ chain (234-)

N-Methyl D-aspartate receptor subtype 2A (NR2A; 1129-)

Ryanodine receptor, skeletal muscle (4209-)

Serine/threonine protein kinase receptor R5 (ALK-3; 423-)

Tyrosine protein kinase receptor EPH (84-)

Total $37.6 \mu \mathrm{g} / \mathrm{mg}$ of cellular proteins

Vitronectin receptor $\alpha$ subunit (CD51; 987-)

( $68.6 \%$ comes into the membrane fraction)

Table 4-2 Amount of membrane receptors in the tissue-liver cells (biopsy)

\begin{tabular}{lll}
\hline HCC portion (No. 6 patient) $\quad$ (in the state of cancer) & & \\
\hline Acetylcholine receptor protein, $\beta$ chain (64-) & membrane & 0.66 \\
Acetylcholine receptor protein, $\varepsilon$ chain (79-) & sup & 1.9 \\
Atrial natriuretic peptide clearance receptor (ANP-C; 36-) & membrane & 0.24 \\
CI Man-6-P receptor (IGF2R; 167-2491) & sup & 28.0 \\
Fibroblast growth factor receptor 1 (BFGF-R; 315-) & membrane & 1.0 \\
Fibroblast growth factor receptor 2 (316-) & membrane & 1.0 \\
Fibronectin receptor $\beta$ subunit (Integrin $\beta-1 ;$ CD29; 761-) & membrane & 0.09 \\
\hline
\end{tabular}




\begin{tabular}{|c|c|c|}
\hline Glycine receptor $\alpha 2$ chain (Glycine receptor subunit $\alpha-2 ; 220-$ ) & sup & 6.5 \\
\hline Interferon- $\alpha$ receptor (331-) & sup & 0.41 \\
\hline Interleukin-7 receptor $\alpha$ chain (IL-7RA; 326-) & membrane & 0.29 \\
\hline Laminin receptor (Colon carcinoma laminin-binding protein; 6-) & membrane & 0.48 \\
\hline Platelet membrane glycoprotein IIIA (CD61; Integrin $\beta-3 ; 145-788$ ) & sup & 6.1 \\
\hline Prolactin receptor type 2 (PRL-R; 169-) & sup & 6.4 \\
\hline Rhodopsin (242-) & sup & 2.8 \\
\hline \multirow[t]{2}{*}{ TGF-beta receptor type III (TGFR-3; 273-) } & sup & 5.0 \\
\hline & \multicolumn{2}{|c|}{$\begin{array}{r}\text { Total } 60.5 \mu \mathrm{g} / \mathrm{mg} \text { of cellular proteins } \\
(6.2 \% \text { comes into the membrane fraction })\end{array}$} \\
\hline \multicolumn{3}{|l|}{ HCC (with Primary Biliary Cirrhosis; PBC) (in the state of cancer) } \\
\hline 5-Hydroxytryptamine receptor 2A (serotonin receptor 2A; 78-) & membrane & 2.5 \\
\hline B2 Bradykinin receptor (BK-2 receptor; 329-) & sup & 1.4 \\
\hline $\begin{array}{l}\text { CD30L receptor (Ki-1 antigen; Tumor necrosis factor receptor } \\
\text { superfamily member } 8 ; 296-)\end{array}$ & sup & 4.2 \\
\hline CD40 ligand (T cell antigen GP39; 138-) & sup & 3.5 \\
\hline Erb b-2 receptor protein-tyrosine kinase (375-) & membrane & 6.7 \\
\hline fMet-Leu-Phe receptor (FMLP receptor; FPR; 288-) & membrane & 0.44 \\
\hline Growth hormone receptor (GH receptor; 437-) & sup & 14.6 \\
\hline Interferon- $\alpha$ receptor (IFN-R-1; 205-) & sup & 11.2 \\
\hline Vitronectin receptor $\alpha$ subunit (CD51; 515-) & sup & 21.3 \\
\hline $\begin{array}{l}\text { Total } 63.2 \mu \mathrm{g} / \mathrm{mg} \text { of cellular proteins } \\
(15.2 \% \text { comes into the membrane fraction) }\end{array}$ & & \\
\hline
\end{tabular}

*PDMD method was used (Hayakawa \& Nagamine, 2014, pp. 93-114). Membrane was defined as a subfraction that precipitated with an ultracentrifuge machine at $100,000 \mathrm{x} \mathrm{g}, 90 \mathrm{~min}$, at $4^{\circ} \mathrm{C}$.

Definition or diagnosis of liver cancer is then necessary; i.e., two HCC portions and HepG2 (without fucoidan) are found to be co-infected with Human immunodeficiency virus type 1 (HIV-1) or Simian immunodeficiency virus (SIV) and with Hepatitis C virus $(H C V)$, but pseudo-cancer liver is not co-infected with $H C V$ (data not shown). Co-infections by the Hepatitis $B$ virus (HBV; dsDNA virus), Human immunodeficiency virus type 2 $(H I V-2)$, and the non-simian retrovirus such as Avian rous-associated virus (RAV), Rous sarcoma virus (RSV), Bovine immunodeficiency virus (BIV), Bovine leukemia virus (BLV), Feline immunodeficiency virus (FIV), and AKT8 Murine leukemia virus (MLVAT) are not essential. Therefore, cancers occurring in other organs besides liver may be co-infected with $H I V-1$ or $S I V$ together with some inflammatory +ssRNA virus. It may be interesting that human coronavirus $229 \mathrm{E}$ ( $H C o V-229 \mathrm{E})$ is detected, but $H I V-1$ is not detectable, in the serum of the gastritis patient. $H C o V-229 E$ is also detected in the serum of a healthy female (52 y), but $H I V-1$ is not present HepG2 (without fucoidan) is also co-infected with $H C o V-229 E(6.8 \mu \mathrm{g} / \mathrm{mg}$ of cell total protein) and $H I V-1$ (13.8 $\mu \mathrm{g} / \mathrm{mg}$ of cell total protein), but their content is dramatically reduced; i.e., cured-state HepG2 after fucoidan treatment contains only $1.1 \mu \mathrm{g} / \mathrm{mg}$ of cell total protein of these two vira. It is noteworthy that co-infection is unsuitable representation, and co-expression of viral proteins of two viruses is more suitable; i.e., genomic information of $\mathrm{HIV}-1$ and $\mathrm{HCV}$ (and possibly $\mathrm{HCoV}$ ) is able to be integrated or lysogenizes into the host cells' DNA using simian reverse transferase of $H I V-1$ and $S I V$, and sometimes the re-expression of proteins of the latent-state or lysogenized-state occurs via separation from the host DNA. Thus, we have also found that the co-expression of $H I V-1 / S I V$ Gag polyprotein and peptidase-containing $H C V$ Genome polyprotein is the marker of HCC (Table 5). Therefore, protease inhibitors such as antithrombin III (AT III), plasminogen activator inhibitor-1 (PAI-1), cystatin-SN, and serpin B6 (placental thrombin inhibitor) are frequently detectable in HCC tissues (our unpublished observation). 
It is noteworthy that bacterial coinfection is occurring in the liver of leprosy; i.e., DNAJ protein of $\mathrm{Myco}$ bacterium leprae $(12.0 \mu \mathrm{g} / \mathrm{mg}$ of cell total protein), and wide host range VirA protein $(8.1 \mu \mathrm{g} / \mathrm{mg}$ of cell total protein and $\beta$-glucosidase $(0.29 \mu \mathrm{g} / \mathrm{mg}$ of cell total protein) of Agrobacterium tumefaciens are detected. But, fMet-Leu-Phe receptor is not expressed in this tissue (Table 4-1). Therefore, Agrobacterium tumefaciens can hydrolyze bacterial fMet-Leu-Phe peptide, and the fMet-Leu-Phe of Mycobacterium leprae is also metabolized by the co-infected Agrobacterium tumefaciens. Thus, impaired immunity against the co-infection of bacteria may also be occurred in the leprosy patient.

Table 5. The presence of $H I V-1 / S I V$ Gag polyprotein and peptidase-containing $H C V$ Genome polyprotein determines the cancer state of $\mathrm{HCC}$

$H I V-1 / S I V$ Gag polyprotein peptidase-containing $H C V$ Genome polyprotein

\begin{tabular}{lll}
\hline Normal fetal cell (USA) & & \\
$\mathrm{Hc}$ & Not exist & Exist \\
(mixture of fetal livers) (mixture of fetal livers) & &
\end{tabular}

(mixture of fetal livers) (mixture of fetal livers)

Cancer cell derived from HCC (USA)

HepG2 (- fucoidan) Exist Exist

(15 y, Caucasian male)

Cured cancer cell by fucoidan $(0.102 \mathrm{mg} / \mathrm{mL}, 3$ day)

HepG2 (+ fucoidan) Not exist Not exist

Non cancer cell but inflammatory (Japanese)

$\begin{array}{lll}\begin{array}{l}\text { Pseudo cancer } \\ (55 \text { y, male })\end{array} & \text { Exist } & \text { Not exist } \\ \begin{array}{l}\text { LC tissue of Leprosy } \\ (66 \text { y, female })\end{array} & \text { Not exist } & \text { Exist } \\ \begin{array}{l}\text { No. } 6, \text { LC tissue } \\ (61 \text { y, male })\end{array} & \text { Not exist } & \text { Not exist }\end{array}$

Cancer cell (HCC)

No. 6, HCC tissue

Exist $\quad$ Exist

(61 y, male)

HCC tissue of PBC Exist Exist

(70 y, female)

PDMD method was used (Hayakawa \& Nagamine, 2014). HCC; hepatocellular carcinoma, LC; liver cirrhosis, PBC; primary biliary cirrhosis.

Therefore, cancer can be induced by such excess stimuli as electromagnetic waves (ultraviolet light, X-ray, $\gamma$ ray, radio wave, vicinity to the high-tension wire), radio isotopes, reactive oxygen species, many chemical carcinogens (aflatoxin, diethylnitrosamine (DEN)), asbestos, stresses, insomnia, excess of hormones, and excess of metals and vitamins (Hayakawa \& Nagamine, 2014). Simultaneously to this co-expression of vira, changes in differentiation may also be induced; i.e., biotin biosynthesis occurs in cancer cells (Keränen, 1972). Therefore, fucoidan of Japanese edible-brown-alga Mozuku adequately cures or moderates the differentiation of biotin biosynthesis and the exasperated recycle of biotin by BIN, together with the inhibition of multiplication against +ssRNA virus (Hayakawa \& Nagamine, 2014). Further, it seems interesting that the scanties of these stimuli do not induce cancer, but induce other diseases; i.e., infectious disease due to low immunity, reduced velocity of growth and development for children, and neuronal diseases like Alzheimer and dementia in the elderly. Therefore, adequate nutrition (biotin, lipoic acid, balenine), tea and coffee (caffeine), tobacco (nicotine), and alcohol consumption become an important issue for the elderly. Further, it is noteworthy that histone H3.1 is the major protein in the immortal cell lines including normal fetal Hc cells; i.e., such differentiation is easy to occur from cancer cells and fetal cells (Hayakawa et al., 2003). Therefore, we believe that the special repression of histone $\mathrm{H} 3.1$ gene is the most important issue to safely achieve regenerative medicine. 
Furthermore, the neuronal diseases may have already been occurring in the late-stage of HCC patients since hormone metabolisms might have been impaired. Thus, it is recommended that the terminal-cancer patient should live comfortably with one's family, to avoid hospitalization to prevent the transmission of $H C V$ caused by intra-hospital (nosocomial) transmission. Home fucoidan therapy without side effect is also a good choice for such a patient using the foodstuff of fucoidan or Mozuku (Hayakawa \& Nagamine, 2015).

\subsection{Human Breast Milk as an Excellent Nutrition}

The protein component from human breast milk obtained from a volunteer mother ( 9 months post partum), and commercially available bovine milk samples (grocery stores) have been analyzed using a protein-direct-microsequencing-deciphering (PDMD) method, and compared. The result is summarized in Table 6. Interestingly, only human breast milk has membrane-receptor proteins, and bovine milk has no detectable levels. Vasoactive intestinal polypeptide receptor 1 (VIP-R-1) has been found in human milk (Table 6), and VIP is a 28-mer peptide known to act as a regulator of circadian rhythms and sleep on the suprachiasmatic nucleus $(\mathrm{SCN})$ of the hypothalamus in the brain. BIN activity is detectable only in human breast milk (Oizumi \& Hayakawa, 1988), but not detectable in bovine milk (Table 6). These differences in protein composition between human and bovine is not surprising, since $\beta$-lactoglobulin and $\alpha$-S2-casein is only present in the bovine milk as these can cause a cow's milk allergy. Human breast milk is produced by the signal of prolactin, which increases during sleep. Therefore, sleep is important for both the infant and mother.

Table 6 . Superiority of human breast milk as compared to bovine milk

\begin{tabular}{|c|c|c|}
\hline & Human breast milk & Bovine milk \\
\hline \multicolumn{3}{|l|}{ Membrane receptor proteins ( $\mu \mathrm{g} / \mathrm{mg}$ of milk protein) } \\
\hline Macrophage mannose receptor 1 (381-) & 10.7 & \\
\hline Vasoactive intestinal polypeptide receptor 1 (VIP-R-1; 80-) & 3.6 & \\
\hline Olfactorin (Uromodulin-like 1; 1103-) & 4.3 & \\
\hline Synaptotagmin-1 (291-) & 5.5 & \\
\hline Total & $24.1 \mu \mathrm{g} / \mathrm{mg}$ of milk protein & Not detectable \\
\hline \multicolumn{3}{|c|}{ Milk biotinidase and lipoamidase proteins ( $\mu \mathrm{g} / \mathrm{mg}$ of milk protein) } \\
\hline Milk biotinidase (1-) & 5.5 & \\
\hline Milk lipoamidase (N-terminal G blocked)** & $(21.8)$ & \\
\hline Kidney-type urine biotinidase (1-) & 4.0 & \\
\hline Total & $31.3 \mu \mathrm{g} / \mathrm{mg}$ of milk protein & $\mathrm{ND} * * *$ \\
\hline \multicolumn{3}{|c|}{ Milk biotinidase and lipoamidase activity ( $\mathrm{pmol} / \mathrm{min} / \mathrm{mg}$ of milk protein) } \\
\hline Milk biotinidase activity & 41.0 & $0.0^{\#}$ \\
\hline Milk lipoamidase activity & 71.7 & ND \\
\hline \multicolumn{3}{|l|}{ Concentrations of biotin and lipoic acid $(\mu \mathrm{g} / \mathrm{mL})$} \\
\hline \multirow[t]{3}{*}{ Biotin } & 0.376 (total) & 0.364 (May, total) \\
\hline & 0.209 (free) & 0.248 (May, free) \\
\hline & & $\begin{array}{r}0.164 \text { (February, total) } \\
0.070 \text { (February, free) }\end{array}$ \\
\hline \multirow[t]{3}{*}{ Lipoic acid } & 62.6 (total) & 26.5 (May, total) \\
\hline & 13.2 (free) & ND (May, free) \\
\hline & & $\begin{array}{rr}16.1 & \text { (February, total) } \\
2.8 & \text { (February, free) }\end{array}$ \\
\hline
\end{tabular}

\footnotetext{
* Human breast milk was taken after 9-mo of the parturition (in November). ND; not yet determined.

${ }^{* *}$ As reportedly in (Hayakawa \& Oizumi, 1988, pp. 345-351).

*** Amino acid sequence of bovine milk BIN is not yet available, and the bovine milk BIN may not be present.

\# It is noteworthy that commercially available bovine homogenized milk (Glico-Youji-Yuhryou-milk; Glico Co., Osaka, Japan) showed no BIN activity.
} 
The role of BIN in the human breast milk is not fully understood, however milk BIN is distinctively different from serum BIN; i.e., activation by 2-mercaptoethanol is larger in the milk BIN, and milk BIN is $O$-glycosylated, whereas serum BIN is $N$-glycosylated (Oizumi, Hayakawa, \& Hosoya, 1989). Therefore, human-milk BIN is considered to be synthesized in the mammary gland. Free and total biotin concentrations in human milk are similar to bovine milk (Table 6), and another role of human-milk BIN is expected. Thus, we have expected that the human-milk BIN may contribute to brain and/or nerve development like membrane-receptor proteins, and to establish the circadian rhythm. Further, human-milk BIN shows a day-to-day cyclic rhythm (our unpublished result), and this rhythm of milk BIN may also strongly contribute to create the biological rhythms in the infant brain. Interestingly, hen's egg-yolk also contains abundant BIN activity (Hayakawa \& Nagamine, 2014), and biotin concentration is high; i.e., total biotin is $13.6 \mu \mathrm{g} / \mathrm{g}$ wet weight, and $90 \%$ is present as free-form biotin. Then, the egg-yolk BIN has also another role than biotin recycling; i.e., egg-yolk BIN may also contribute to the brain and/or nerve development of the chick. Biotin content is very high in soy milk; i.e., $2.98 \mu \mathrm{g} / \mathrm{mL}$ (free-form $1.99 \mu \mathrm{g} / \mathrm{mL}$ ), however soy milk contains no nervous receptor proteins and milk BIN. Therefore, human breast milk seems superior to bovine milk and to soy milk.

Furthermore, human breast milk has $2.9 \mu \mathrm{g} / \mathrm{mg}$ of milk protein of $\mathrm{Ig} \delta$ chain C region and $4.2 \mu \mathrm{g} / \mathrm{mg}$ of milk protein of Ig $\kappa$ chain V-II region RPMI 6410, but bovine milk does not. Thus, human breast milk helps the infant to create a healthy immunological condition.

\section{Conclusion}

1) Human serum biotinidase has turned out to be the dimer enzyme, and this enzyme seems to hydrolyze enkephalin physiologically in human blood due to Fascio effect ( $\mathrm{Km}$ to Leu-enkephalin substrate is estimated to be $30.3 \mu \mathrm{M})$.

2) Human blood is the main route for many peptide hormones, and important metabolic role of human serum biotinidase for neuro-peptides is suggested.

3) It is shown that adequate biotin amount is important for membrane biosynthesis.

4) Definition of liver cancer is presented; i.e., presence of $H I V-1 / S I V$ Gag polyprotein and peptidase-containing $H C V$ Genome polyprotein determines the cancer state.

5) Human breast milk is shown to superior to bovine milk, since human biotinidase, membrane receptors, and sleep are provided from mother.

\section{Acknowledgements}

This work was supported by the grants from the Ministry of Welfare, Labour and Health, Japan. This work was also partially supported by the scientific inquiry subsidy of the Ministry of Education, Culture, Sports, Science and Technology, Japan. Authors are grateful to Dr. Kentaro Deguchi, M.D. (Department of Neurology, Graduate School of Medicine and Dentistry, Okayama University, Okayama, Okayama, Japan), Dr. Kiyomi Abe, M.D. (Department of Pediatrics, School of Medicine, Keio University, Shinjuku-ku, Tokyo, Japan, formerly; Department of Endocrinology and Metabolism, National Research Institute for Child Health and Development, Setagaya-ku, Tokyo, Japan), and the Tokyo Metropolitan Hospital for Mothers and Children (Tokyo-Boshi-Hoken-in-Hospital; now closed; Setagaya-ku, Tokyo, Japan) for their kind donations of human sera and human breast milk (at 9 months after parturition), and a plentiful human breast milks (between 0 to 12 months after parturitions). K.H. is very grateful to Dr. Alaa Otaibi (Department of Prosthetic Dental Science, King Saud University, Riyadh, Riyadh, Saudi Arabia) for his kind discussion about the Km problemn. K.H. is also very grateful to Late Dr. Tatsuro Haruki, Ph.D. (Shimadzu Co., Kyoto, Japan) for introducing the HPLC technology, to Late Hon. Prof. Dr. Kunio Yamauchi, Ph.D. (The University of Tokyo, Tokyo, Japan) for his kind encouragement for applying RP-HPLC to $\mathrm{Km}$ studies and giving the information about human breast milk and bovine milk, and to Hon. Prof. Dr. Iwao Kusaka, Ph.D. (The Institute of Applied Microbiology, University of Tokyo, Tokyo, Japan) for introducing the membrane biology, respectively.

Dedication: In memory of the encouragement of my beloved daughter Reiko Hayakawa (21 November 1979 - 1 February 2007).

\section{References}

Abe, K., Hayakawa, K., Ihara, K., Deguchi, K., \& Nagamine, T. (2015). Changes in the hydrophobic proteins in response to biotin administration in serum of infant patients with alopecia as assessed by the protein micro-sequencing method. Journal of Microbiological \& Biochemical Technology, 7, 39-46. http://dx.doi.org/10.4172/1948-5948.1000179 
Banting, F. G., Best, C. H., Collip, J. B., Cambell, W. R., Fletcher, A. A., Macleod, J. J. R., \& Noble, E. C. (1922). The effect produced on diabetes by extractions of pancreas. Transactions of the Association of American Physicians, 37, 337-347.

Chauhan, J., \& Dakshinamurti, K. (1986). Purification and characterization of human serum biotinidase. Journal of Biological Chemistry, 261, 4268-4275. Retrieved from http://www.jbc.org/content/261/9/4268.full.pdf +html

Chern, C-K., Kusaka, I., \& Fukui, S. (1976) Significance of pyruvate carboxylase in sugar metabolism of Agrobacterium tumefaciens. Agricultural and Biological Chemistry, 40, 771-778. http://dx.doi.org/10.1080/ 00021369.1976 .10862115

De Felice, C., Hayakawa, K., Nihei, K., Higuchi, S., Tanaka, T., Watanabe, T., \& Hibi, I. (1994) Changes in cerebrospinal fluid biotinidase activity in Staphylococcus aureus meningitis. Brain \& Development, 16, 156-158. http://dx.doi.org/10.1016/0387-7604(94)90055-8

Halaas, J. L., Gajiwala, K. S., Maffei, M., Cohen, S. L., Chait, B. T., Rabinowitz, D., ... Friedman, J. M. (1995) Weight-reducing effects of the plasma protein encoded by the obese gene. Science, 269, pp. 543-546. http://dx.doi.org/10.1126/science.7624777

Hayakawa, K. (2015) Moderation in taking nutrition of Vitamin H (Biotin) keeps the doctor away. International Journal of Science and Engineering (EPH), 1, 1-37. Retrieved from http://ephjournal.com/EPH-Pdf/ International-Journal-of-Science-and-Engineering/October-2015/International-Journal-of-Science-and-Engi neering-1.pdf

Hayakawa, K., \& Fukui, S. (1980) Changes in electrophoretic pattern of cellular proteins in response to mating hormone in Tremella mesenterica. Journal of General and Applied Microbiology, 26, 63-69. http://doi.org/ $10.2323 /$ jgam. 26.63

Hayakawa, K., \& Nagamine, T. (2009) Effect of fucoidan on the biotinidase kinetics in human hepatocellular carcinoma. Anticancer Research, 29, 1211-1218. Retrieved from http://ar.iiarjournals.org/content/29/4/ 1211.short

Hayakawa, K., \& Nagamine, T. (2014) Fucoidan-dependent increased membrane component in HepG2: effect of fucoidan is not due to gene expression. Cancer Genomics \& Proteomics, 11, 93-114. Retrieved from http://cgp.iiarjournals.org/content/11/2/93.full.pdf

Hayakawa, K., \& Nagamine, T. (2015) Prevention of swelling of liver tumor in Sprague-Dawley rat fed with the Kinu-Mozuku, an edible Japanese brown alga grown at seashores in Noto-peninsula. Journal of Applied Science, International Journal of Research and Development Organization, 2, 15-34. Retrieved from https://www.researchgate.net/publication/281852977_Prevention_of_swelling_of_liver_tumor_in_SpragueDawley_rat_fed_with_the_Kinu-Mozuku_an_edible_Japanese_brown_alga_grown_at_seashores_in_Notopeninsula

Hayakawa, K., \& Oizumi, J. (1988) Isolation and characterization of human breast milk lipoamidase. Biochimica et Biophysica Acta, 957, 345-351. http://dx.doi.org/10.1016/0167-4838(88)90224-5

Hayakawa, K., Guo, L., Terentyeva, E. A., Li, X-K., Kimura, H., Hirano, M., ...Tanaka, T. (2003) Size-exclusion chromatography of biological samples which contain extremely alkaline proteins. Journal of Biochemical and Biophysical Methods, 56, 153-163. http://dx.doi.org/10.1016/S0165-022X(03)00056-3

Hayakawa, K., Guo, L., Terentyeva, E. A., Li, X-K., Kimura, H., Hirano, M., ... Tanaka, T. (2006) Determination of specific activities and kinetic constants of biotinidase and lipoamidase in LEW rat and Lactobacillus casei (Shirota). Journal of Chromatography B, 844, 240-250. http://dx.doi.org/10.1016/j. jchromb.2006.07.006

Hayakawa, K., Yoshikawa, K., \& Watanabe, T. (1994) Biotinidase: determination of enzyme activity, chemical structure such as glycochain structure and amino-acid sequence, and potential physiological role and possibility onto clinical application. Vitamins (Kyoto), 68, 318-320 (in Japanese).

Huet, Y., Straßner, J., \& Schaller, A. (2008) Cloning, expression and characterization of insulin-degrading enzyme from tomato (Solanum lycopersicum). Biological Chemistry, 389, 91-98. http://dx.doi.org/10. 1515/BC.2008.006 
Hughes, J., Smith, T. W., Kosterlitz, H. W., Fothergill, L. A., Morgan, B. A., \& Morris, H. R. (1975) Identification of two related pentapeptides from the brain with potent opiate agonist activity. Nature, 258, 577-580. http://dx.doi.org/10.1038/258577a0

Hui, D. Y., Hayakawa, K., \& Oizumi, J. (1993) Lipoamidase activity in normal and mutagenized pancreatic cholesterol esterase (bile salt-stimulated lipase). Biochemical Journal, 291, 65-69. http://dx.doi.org/10.1042/bj2910065

Keränen, A. J. A. (1972) The biotin synthesis of HeLa cells in vitro. Cancer Research, 32, 119-124. Retrieved from http://cancerres.aacrjournals.org/content/32/1/119.full.pdf

Klok, M. D., Jakobsdottir, S., \& Drent, M. L. (2007) The role of leptin and ghrelin in the regulation of food intake and body weight in humans: a review. Obesity Reviews, 8, 21-34. http://dx.doi.org/10.1111/j.1467 -789X.2006.00270.x

Koivusalo, M., \& Pispa, J. (1963) Biotinidase activity in animal tissues. Acta Physiologica Scandinavica, 58, 13-19. http://dx.doi.org/10.1111/j.1748-1716.1963.tb02623.x

Kojima, M., Hosoda, H., Date, Y., Nakazato, M., Matsuo, H., \& Kangawa, K. (1999) Ghrelin is a growth-hormone-releasing acylated peptide from stomach. Nature, 402, 656-660. http://dx.doi.org/10. $1038 / 45230$

Kothapalli, N., Camporeale, G., Kueh, A., Chew, Y. C., Oommen, A. M., Griffin, J. B., \& Zempleni, J. (2005) Biological functions of biotinylated histones. Journal of Nutritional Biochemistry, 16, 446-448. http://dx.doi.org/10.1016/j.jnutbio.2005.03.025

Levenson, J. L. (1983) Biotin-responsive depression during hyperalimentation. Journal of Parenteral \& Enteral Nutrition, 7, 181-183. http://dx.doi.org/10.1177/0148607183007002181

Matsuzawa, H., Hayakawa, K., Sato, T., \& Imahori, K. (1973) Characterization and genetic analysis of a mutant of Escherichia coli K-12 with rounded morphology. Journal of Bacteriology, 115, 436-442. Retrieved from https://www.researchgate.net/publication/18587904_Characterization_and_genetic_analysis_of_a mutant_of_Escherichia_coli_K_12_with_rounded_morphology

Monnier, M., Dudler, L., Gachter, R., Maier, P. F., Tobler, H. J., \& Schönenberger, G. A. (1977) The delta sleep inducing peptide (DSIP). Comparative properties of the original and synthetic nonapeptide. Experientia, 33, 548-552. http://dx.doi.org/10.1007/BF01922266

Oizumi, J., \& Hayakawa K. (1989) Liberation of lipoate by human serum lipoamidase from bovine heart pyruvate dehydrogenase. Biochemical and Biophysical Research Communications, 162, 658-663. http://dx.doi.org/10.1016/0006-291X(89)92361-9

Oizumi, J., \& Hayakawa, K. (1988) Biotinidase in human breast milk. American Journal of Clinical Nutrition, 48, 295-297. Retrieved from https://www.researchgate.net/publication/19747942_Biotinidase_in_human _breast_milk

Oizumi, J., \& Hayakawa, K. (1990a) Biotinidase in the porcine cerebrum. Archives of Biochemistry and Biophysics, 278, 381-385. http://dx.doi.org/10.1016/0003-9861(90)90274-3

Oizumi, J., \& Hayakawa, K. (1990b) Lipoamidase (lipoyl-X hydrolase) from pig brain. Biochemical Journal, 266, 427-434. http://dx.doi.org/10.1042/bj2660427

Oizumi, J., \& Hayakawa, K. (1990c) Lipoamidase is a multiple hydrolase. Biochemical Journal, 271, 45-49. http://dx.doi.org/10.1042/bj2710045

Oizumi, J., \& Hayakawa, K. (1991) Enkephalin hydrolysis by human serum biotinidase. Biochimica et Biophysica Acta, 1074, 433-438. http://dx.doi.org/10.1016/0304-4165(91)90096-Y

Oizumi, J., \& Hayakawa, K. (1992) Release of anchored membrane enzymes by lipoamidase. Molecular and Cellular Biochemistry, 115, 11-17. Retrieved from http://link.springer.com/article/10.1007\%2FBF00229090

Oizumi, J., \& Hayakawa, K. (1993) Biocytin-specific $110 \mathrm{kDa}$ biotinidase from the human serum. Clinica Chimica Acta, 215, 63-71. http://dx.doi.org/10.1016/0009-8981(93)90249-4

Oizumi, J., Hayakawa, K., \& Hosoya, M. (1989) Comparative study on human milk and serum biotinidase. Biochimie, 71, 1163-1169. http://dx.doi.org/10.1016/0300-9084(89)90019-9 
Sakurai, T., Amemiya, A., Ishii, M., Matsuzaki, I., Chemelli, R. M., Tanaka, H., ...Yanagisawa, M. (1998) Orexins and orexin receptors: A family of hypothalamic neuropeptides and $\mathrm{G}$ protein-coupled receptors that regulate feeding behavior. Cell, 92, pp. 573-85. http://dx.doi.org/10.1016/S0092-8674(00)80949-6

Suchy, F., McVoy, B. S., \& Wolf, B. (1985) Neurologic symptoms of biotinidase deficiency: possible explanation. Neurology, 35, 1510-1511. http://dx.doi.org/10.1212/WNL.35.10.1510

Terashi, M., Asakawa, A., Harada, T., Ushikai, M., Coquerel, Q., Sinno, M. H., .. Fetissov, S. O. (2011) Ghrelin reactive autoantibodies in restrictive anorexia nervosa. Nutrition, 27, 407-413. http://dx.doi.org/10.1016/j.nut.2011.01.002.

Terentyeva, E. A., Hayakawa, K., Tanae, A., Katsumata, N., Tanaka, T., \& Hibi, I. (1997) Urinary biotinidase and alanine excretion in patients with insulin-dependent diabetes mellitus. European Journal of Clinical Chemistry and Clinical Biochemistry, 35, 21-24. http://dx.doi.org/10.1515/cclm.1997.35.1.21

Van Cauter, E., \& Plat, L. (1996) Physiology of growth hormone secretion during sleep. Journal of Pediatrics, $128, \mathrm{~S} 32-\mathrm{S} 37$.

Weikel, J. C., Wichniak, A., Ising, M., Brunner, H., Friess, E., Held, K., ... Steiger, A. (2003) Ghrelin promotes slow-wave sleep in humans. American Journal of Physiology: Endocrinology and Metabolism, 284, E407-E415.

Wright, L. D., Driscoll, C. A., \& Boger, W. P. (1954) Biocytinase, an enzyme concerned with hydrolytic cleavage of biocytin. Proceedings of the Society for Experimental Biology and Medicine (New York), 86, 335-337. Retrieved from http://ebm.sagepub.com/content/86/2/335.short

\section{Copyrights}

Copyright for this article is retained by the author(s), with first publication rights granted to the journal.

This is an open-access article distributed under the terms and conditions of the Creative Commons Attribution license (http://creativecommons.org/licenses/by/3.0/). 